\title{
PENGARUH KONSUMSI HARIAN SUSU KACANG KEDELAI (Glycine $\max ($ L.)Merr) TERHADAP PENURUNAN KADAR KOLESTEROL TOTAL DARAH PADA MENCIT JANTAN (Mus musculus) YANG HIPERKOLESTEROL
}

\author{
Dian Amelia Abdi ${ }^{1}$, Dwi Anggita ${ }^{2}$ dan Rihlah Thahirah Al-Hikmah ${ }^{3}$ \\ ${ }^{1}$ Bagian Kulit dan Kelamin Fakultas Kedokteran Universitas Muslim Indonesia Makassar \\ ${ }^{2}$ Bagian Fisiologi Fakultas Kedokteran Universitas Muslim Indonesia Makassar \\ ${ }^{3}$ Mahasiswa Pre Klinik Fakultas Kedokteran Universitas Muslim Indonesia Makassar
}

\begin{abstract}
Abstrak
Latar Belakang : Dislipidemia merupakan suatu kelainan metabolisme lipid yang ditandai dengan peningkatan kadar kolesterol total, trigliserida, LDL, dan penurunan HDL di dalam serum. Didalam susu kacang kedelai mengandung isoflavon yang terdiri atas genistein dan daidztein, dan protein kedelai yang dapat menurunkan resiko penyakit kardiovaskular dengan cara mengikatkan profil lemak darah. Khususnya, protein kedelai menyebabkan penurunan yang nyata dalam kolesterol total. Metode Penelitian : Penelitian ini menggunakan pre-post true experimental test group design dengan menggunakan 24 hewan coba yang hiperkolesterol yang dibagi menjadi 3 kelompok dengan total masing-masing kelompok sebanyak 8 ekor mencit. Kelompok kontrol negatif yang diberi aquades, kelompok kontrol positif diberi simvastatin $0.244 \mathrm{mg} / 30$ gBB mencit/hari, dan kelompok perlakuan yang diberi susu kacang kedelai $0.154 \mathrm{~g} / 30$ gBB mencit/hari dengan total intervensi 14 hari. Hasil Penelitian : Hasil penelitian menunjukkan Rerata kadar Kolesterol total darah mencit pada hari ke-7 pemberian susu kacang kedelai (Glycine $\max ($ L.)Merr) adalah $185 \mathrm{mg} / \mathrm{dl}$ dan pada hari ke-15 adalah 139 $\mathrm{mg} / \mathrm{dl}$. Terdapat perbedaan kadar kolesterol total pada mencit tiap kelompok yang cukup signifikan yakni kelompok kontrol negatif dengan mengalami kenaikan yang signifikan sebesar $6 \mathrm{mg} / \mathrm{dl}$ ( $\mathrm{p}=0.06$ ), kelompok kontrol positif mengalami penurunan yang signifikan sebesar $31 \mathrm{mg} / \mathrm{dl}(\mathrm{p}=0.00)$ dan kelompok perlakuan mengalami penurunan signifikan sebesar $46 \mathrm{mg} / \mathrm{dl}(\mathrm{p}=0,00)$ sehingga ada pengaruh konsumsi harian susu kacang kedelai (Glycine max (L.) Merr) terhadap penurunan kadar kolesterol pada mencit jantan (Mus musculus) yang hiperkolsterol. Kesimpulan : Diantara ketiga kelompok, yang paling signifikan penurunan kadar kolesterolnya ada pada susu kacang kedelai dibandingkan kelompok simvastatin sedangkan pada kelompok pemberian aquades terjadi peningkatan kadar kolesterol total pada mencit (Mus musculus). Kata Kunci : Susu Kacang Kedelai Glycine $\max$ (L.) Merr , Kadar Kolesterol Total, Mus musculus
\end{abstract}




\section{PENDAHULUAN}

Dislipidemia merupakan suatu kelainan metabolisme lipid yang ditandai dengan peningkatan kadar kolesterol total, trigliserida, LDL, dan penurunan HDL di dalam serum. ${ }^{1}$ Kadar LDL serum yang meningkat akan memicu terjadinya aterosklerosis. ${ }^{2}$

Berdasarkan Survey Kesehatan Rumah Tangga (SKRT) tahun 2011 menunjukkan bahwa penyakit jantung koroner menempati urutan ketiga dalam deretan penyebab kematian di Indonesia. ${ }^{6}$ Berdasarkan Riset Kesehatan Dasar Tahun 2007 rata-rata kadar kolesterol darah pada daerah urban $(212,52)$ lebih tinggi daripada daerah rural $(204,71)$.

Salah satu bahan pangan yang mengandung banyak protein nabati adalah kedelai. Kedelai merupakan salah satu sumber protein nabati yang sering digunakan di Indonesia dan popular di Jepang. Di samping karena murah harganya dan mudah didapat, kedelai juga merupakan sumber lemak, vitamin dan serat. Karena mengandung isoflavon yang terdiri atas genistein dan daidztein, protein kedelai dapat menurunkan resiko penyakit kardiovaskular dengan cara mengikatkan profil lemak darah. Khususnya, protein kedelai menyebabkan penurunan yang nyata dalam kolesterol total. Makanan dari kedelai seperti tahu, susu kedelai, tepung kedelai dan kedelai utuh mempunyai kandungan isoflavon berkisar antara $130-380 \mathrm{mg} / 100$ gram. ${ }^{9}$

Berdasarkan uraian di atas maka peneliti tertarik untuk melakukan penelitian apakah ada pengaruh penurunan kadar kolesterol total dengan pemberian konsumsi harian susu kacang kedelai pada mencit.

\section{METODE PENELITIAN}

Pada penelitian ini, Pengaruh konsumsi harian susu kacang kedelai (Glycine $\max (\mathrm{L}$.$) Merr.) terhadap kadar$ kolesterol total darah pada mencit jantan(Mus musculus) yang hiperkolesterol menggunakan metode true experimental pre and post control dengan menggunakan hewan coba (probandus) yang dilakukan di Fakultas Farmasi Universitas Muslim Indonesia periode waktu mulai bulan februari sampai dengan bulan april 2017.

Hewan uji yang dipakai adalah 24 ekor mencit (Mus musculus) jantan yang kemudian dibagi menjadi 3 kelompok percobaan, yaitu : kelompok yang diberikan aquades, kelompok yang diberikan Simvastatin dan kelompok yang diberikan susu kacang kedelai (Glycine max. (L.) Merr)

Data yang diperoleh dianalisis secara statistik menggunakan program Statistical Products and Service Solutions (SPSS) for Windows Release 24.0.

\section{HASIL PENELITIAN}

\section{Tabel 1. Data Kadar Kolesterol (mg/dl) Sebelum dan Sesudah Perlakuan}

\begin{tabular}{ccccccc}
\hline \multirow{2}{*}{ Mencit } & \multicolumn{2}{c}{ Kelompok A } & \multicolumn{2}{c}{ Kelompok B } & \multicolumn{2}{c}{ Kelompok C } \\
\cline { 2 - 7 } & Pre & Post & Pre & Post & Pre & Post \\
\hline $\mathbf{1}$ & 150 & 165 & 150 & 119 & 188 & 130 \\
$\mathbf{2}$ & 171 & 181 & 147 & 117 & 175 & 137 \\
$\mathbf{3}$ & 175 & 180 & 158 & 128 & 178 & 101 \\
$\mathbf{4}$ & 190 & 191 & 157 & 126 & 181 & 152 \\
$\mathbf{5}$ & 176 & 189 & 152 & 127 & 154 & 120 \\
$\mathbf{6}$ & 165 & 171 & 142 & 111 & 182 & 129 \\
$\mathbf{7}$ & 170 & 160 & 155 & 120 & 181 & 143 \\
$\mathbf{8}$ & 161 & 170 & 162 & 129 & 239 & 201 \\
\hline $\bar{X}$ & 170 & 176 & 153 & 122 & 185 & 139 \\
\hline & & & & & Sumber: DataPrimer 2017
\end{tabular}


Keterangan :

Kelompok A : Kelompok kontrol negatif (pemberian aquades)

Kelompok B : Kelompok kontrol positif (pemberian simvastatin)

Kelompok C : Kelompok Perlakuan (pemberian susu kacang kedelai)

Dari data hasil tabel 1 dapat disimpulkan bahwa yang diberikan kontrol negatif yaitu pemberian aquades mengalami kenaikan, yang diberikan kontrol positif yaitu pemberian simvastatin mengalami penurunan, dan yang diberikan perlakuan susu kacang kedelai mengalami penurunan yang signifikan.

\section{Tabel 2 Uji Multiple Comparisons}

\begin{tabular}{|c|c|c|c|c|c|c|}
\hline \multirow[b]{2}{*}{$\begin{array}{l}\text { Variabel } \\
\text { dependen }\end{array}$} & \multirow[b]{2}{*}{$\begin{array}{l}\text { (I)kelompok } \\
\text { perlakuan }\end{array}$} & \multirow[b]{2}{*}{$\begin{array}{c}\text { (J)kelompok } \\
\text { perlakuan }\end{array}$} & \multirow[b]{2}{*}{$\begin{array}{c}\text { Mean } \\
\text { difference(I- } \\
\text { J) }\end{array}$} & \multirow[b]{2}{*}{ Sig. } & \multicolumn{2}{|c|}{$\begin{array}{c}\text { Tingkat } \\
\text { kepercayaan } 95 \%\end{array}$} \\
\hline & & & & & $\begin{array}{l}\text { Batas } \\
\text { bawah }\end{array}$ & $\begin{array}{c}\text { Batas } \\
\text { atas }\end{array}$ \\
\hline \multirow[t]{6}{*}{$\begin{array}{c}\text { Kelompok } \\
\text { selisih pre } \\
\text { dan pos } \\
\text { perlakuan }\end{array}$} & $\begin{array}{c}\text { Kelompok } \\
\text { dengan } \\
\text { pemberian } \\
\text { aquades }\end{array}$ & $\begin{array}{c}\text { Kelompok } \\
\text { dengan } \\
\text { pemberian } \\
\text { simvastatin }\end{array}$ & $-36.87^{*}$ & 0.00 & -47.69 & -26.05 \\
\hline & & $\begin{array}{c}\text { Kelompok } \\
\text { dengan } \\
\text { pemberian } \\
\text { susukacang } \\
\text { kedelai }\end{array}$ & -51.75 & 0.00 & -62.56 & -40.93 \\
\hline & $\begin{array}{c}\text { Kelompok } \\
\text { dengan } \\
\text { pemberian } \\
\text { simvastatin }\end{array}$ & $\begin{array}{c}\text { Kelompok } \\
\text { dengan } \\
\text { pemberian } \\
\text { aquades }\end{array}$ & $36.87^{*}$ & 0.00 & 26.05 & 47.69 \\
\hline & & $\begin{array}{l}\text { Kelompok } \\
\text { dengan } \\
\text { pemberian } \\
\text { susukacang } \\
\text { kedelai }\end{array}$ & $-14.87^{\star}$ & 0.01 & -25.69 & -4.05 \\
\hline & $\begin{array}{l}\text { Kelompok } \\
\text { dengan } \\
\text { pemberian } \\
\text { susukacang }\end{array}$ & $\begin{array}{c}\text { Kelompok } \\
\text { dengan } \\
\text { pemberian } \\
\text { aquades }\end{array}$ & $51.75^{*}$ & 0.00 & 40.93 & 62.56 \\
\hline & kedelai & $\begin{array}{c}\text { Kelompok } \\
\text { dengan } \\
\text { pemberian } \\
\text { simvastatin }\end{array}$ & $14.87^{*}$ & 0.01 & 4.05 & 25.69 \\
\hline
\end{tabular}

Berdasarkan pada tabel 2 terdapat perbedaan yang signifikan pada kelompok selisih sebelum dan setelah perlakuan antara kelompok pemberian aquades dengan kelompok pemberian simvastatin yaitu 36.87 dengan nilai sig $0.00<0.05$. Adapun antara kelompok pemberian susu kacang kedelai dengan kelompok pemberian simvastatin terdapat juga perbedaan signifikan yaitu 14.87 dengan nilai sig 0.01 $<0.05$. sedangkan pada kelompok dengan pemberian susu kacang kedelai dengan kelompok pemberian aquadest terdapat juga perbedaan yang signifikan yaitu 51.75 dengan nilai sig $0.00>0.05$.

\section{PEMBAHASAN}

Dalam penelitian, mencit dibagi menjadi 3 kelompok, selain kelompok dosis susu kacang kedelai untuk pengujian penurunan kadar kolesterol total darah pada mencit, terdapat juga kelompok kontrol pembanding. Obat yang mungkin menjadi kontrol pembanding, yaitu simvastatin (golongan statin). Simvastatin (golongan statin) digunakan sebagai kontrol pembanding karena merupakan hipolipidemik yang paling aman dan efektif terutama untuk menurunkan kolesterol dengan menghambat HMG KoA reduktase sehingga dapat menghambat sintesis kolesterol di hati ${ }^{34}$. Selain dapat menurunkan kolesterol hingga 20-45\%, golongan statin juga dapat menurunkan trigliserida sebesar $10-45 \%{ }^{35}$.

Pada penelitian ini didapatkan penurunan signifikan kadar kolesterol total darah mencit yg telah diinduksi susu kacang kedelai. Penurunan kadar kolesterol total darah yang terjadi disebabkan karena susu kacang kedelai mengandung isoflavon yang terdiri atas genistein dan daidztein. Kandungan pada susu kacang kedelai 
tersebut dapat mengikat profil lemak darah sehingga terjadi penurunan penyerapan kolesterol dan asam empedu pada usus halus yang mengakibatkan peningkatan ekskresi fekal asam empedu dan steroid, hati juga lebih banyak mengubah kolesterol dalam tubuh menjadi empedu, yang akibatnya dapat menurunkan kolesterol dan meningkatkan aktifitas reseptor kolesterol LDL, diikuti dengan terjadinya penurunan kadar kolesterol total dalam darah ${ }^{9}$.

\section{KESIMPULAN}

Diantara ketiga kelompok, yang paling signifikan penurunan kadar kolesterolnya ada pada susu kacang kedelai dibandingkan kelompok simvastatin sedangkan pada kelompok pemberian aquades terjadi peningkatan kadar kolesterol total pada mencit (Mus musculus).

\section{DAFTAR PUSTAKA}

1. Departemen Kesehatan Republic Indonesia. Pedoman Pengendalian Penyakit Jantung dan Pembuluh Darah. Jakarta : Departemen Kesehatan RI. 2007

2. Colpo A. LDL cholesterol : Bad Cholesterol or Bad Science. Journal of American Physicians and Surgeons. 2005; 10(3)

3. Brown CT. Penyakit Aterosklerotik Koroner, Dalam : Price, Sylvia A dan Lorraine Wilson, Patofisiologi : Konsep Klinis Proses-Proses Penyakit, Ed ke-6, Vol 1, Penerbit Buku Kedokteran EGC, Jakarta. 2003; 580-588

4. Corwin EJ. Buku Saku Patofisiologi, Ed ke-3. Jakarta : Penerbit Buku Kedokteran EGC. 2007. 477-481
5. WHO Media Centre., Cardiovascular disease (CVDs) Fact Sheet No.317. http://www.who.int/mediacentre/factsheets/f s317/en/index.html. Sept 2011

6. Departemen Kesehatan Republik Indonesia , Survey Kesehatan Rumah Tangga 2012. http://www.depkes.go.id

7. Kementerian Kesehatan Republik Indonesia. Buletin Jendela Data dan Informasi Kesehatan Penyakit Tidak Menular 2012.

8. Varady KA, Kones PJH. Combination Diet and Exercise Interventions for The Treatment of Dyslipidemia : An Effective Preliminary Strategy to Lower Cholesterol Levels. The Journal of Nutrition. 2005; 135: 1829-35.

9. Takahashi, R, Ohmori, R., Kiyose, C., Momiyama, Y., Ohsuzu, F. and Kondo, K. Antioxidant Activities of Black and Yellow Soybeans Againts Low Density Lipoprotein Oxidant. J. Agric Food Chem. 2005; 53: $4578-82$.

10. Supriyanto. Pengaruh Pemberian Ekstrak Kedelai terhadap Kadar Kolesterol Total, LDL, HDL dan Rasio Kolesterol LDL/HDL Darah Tikus Putih Jantan yang Mengalami Hiperkolesterolemia. [Thesis]. Program Pasca Sarjana Universitas Airlangga Surabaya; 2004.

11. Vella, C .A., Kravitz, L., and Janot, J.M. A review of impact of exercise on cholesterol level. 2001. Http://www.unm.edu/-

Ikravitz/articlefolder/cholesterol.

12. Guyton, A. C. and Hall, J.E. Text book of medical physiology, eleventh edition. Elseier saunders. Philladelphia; 2006.

13. King, M.W.,. Cholesterol and bile synthesis and metabolism. 2010. 
Http://themedcialbiochemistry.org/cholester ol.html

14. Setiati $S$ et all. Buku Ajar Ilmu Penyakit Dalam. 6th ed. Jakarta: Interna Publishing; 2549-2550 p.

15. Kosasih E. Tafsiran Hasil Pemeriksaan Laboratorium Klinik. Jakarta: Karisma Publishing; 2008.

16. Sherrwood L. Fisiologi Manusia dari Sel ke Sistem. 6th ed. Jakarta: EGC; 2012.

17. Redha, A. Flavonoid : Struktur, sifat Antioksidatif dan Peranannya Dalam Sstem Biologis 197 Jurnal Belian Vol. 9 No. 2 Sep. 2010. Hal 196-202

18. Pitojo, Setijo.. Seni Penangkaran Benih Kedelai. Yogyakarta: Penerbit Kanisius; 2003. hlm 18-20.

19. Mun'im, Abdul, dan Hanani, Endang. Fitoterapi Dasar. Jakarta: Dian Rakyat; 2003. Hlm 237-239.

20. Heinrich, Michael., Barnes, Joanne., Gibbons, Simon., dan Williamson, Elizabeth.. Fundamentals of Pharmacognosy and Phytoterapy. Toronto : Elsevier Science Limited; 2004. hlm 255.

21. Daniel, M. Medicinal Plants Chemistry and Properties. USA: Science Publishers; 2006. hlm 167-168.

22. Samuelsson, Gunnar. Drugs of Natural Origin A Textbook of Pharmacognosy (4th ed.). Sweeden: Swedish Pharmaceutical Society, Swedish Pharmaceutical Press; 1999. hlm 174-175.

23. Palaniswamy, Usha. Asian Crops and Human Dietetics. New York: The Haworth Press, Taylor and Francis Group; 2008.

24. Sutarno, Hadi. Kedelai. Dalam: Pusat Penelitian dan Pengembangan Biologi-LIPI dan Balai Metodologi
Informasi Pertanian Ciawi-DEPTAN. Lembaran Informasi PROSEA (Plant Resources of South-East Asia). Vol. 1 No. 1. PROSEA Indonesia: PROSEA Fondation; 1993. hlm 7-8.

25. Kusnul, Zauhani. Zaenal Munir. Pengaruh Pemberian Beras yang Difermentasi oleh Monascus Purpureus jmba terhadap Darah Tikus Putih (Rattus Sp.) Hiperkolesterolemia. 2009.

26. Ulbritch, Catherine. Natural Standard Herb \& Supplement Guide: An Evidence-Based Reference. United States of America: Mosby Elsevier Inc; 2010. hlm 667-670.

27. Harrison, Dyslipidemia. Issebacher, dkk. Prinsip-Prinsip Ilmu Penyakit Dalam. Edisi 13. Jakarta ; EGC. 2009. Hlm 10231030.

28. Robbins. Pembuluh Darah. Huriawati Hartanto, dkk. Buku Ajar Patologi. Edisi VII. Jakarta;EGC.2010.Hlm 374-378

29. Amori G. Mus Musculus. 2007 IUCN Red List of Threatened Species; 2007. Retrieved may $3^{\text {rd }} 2014$. Available from : http://www.iucnredlist.org/details/13972/0.

30. Lee Mo. Determination of The Surface Area of The white Rat with its Application to the Expression of Metabolic Results. Br J Nutr. 1929;89;24-33

31. Oze GO, Nwanjo HU, Opera AU, Ojiegbe GC, Nwankpa P, Ihim AC, et al. Effect of yoghurt (milk fermented by Lactobacillus acidophilus) on plasma lipid profiles and blood pressure levels in Nigerian males. Nigerian Journal of Biochemistry and Molecular Biology (Internet). 2008 (Cited 2011 Oct 29); 23 (1): 30-34 
32. Gaw A, Christopher J, Packard MDS, et al. Statins: the HMG CoA Reductase Inhibitors In Perspective. United Kingdom: Taylor \& Francis; 2003.

33. Tiano, Joseph P., et al. Estrogen Receptor Activation Reduces Lipid Synthesis in Pancreatic Islets and Prevents $\beta$ cell Failure in Rodent Models of Type 2 Diabetes. J. Clin Inves. (121), number 8. 2011.

34. Suyatna, F.D. Hipolipidemik. Dalam: Gunawan,S.G., R. Setiabudy, Nafrialdi, Elysabeth (Ed. Farmakologi dan Terapi. (Ed.
Ke-5). Jakarta: Departemen Farmakologi dan Terapeutik Fakultas Kedokteran Universitas Indonesia; 2007. hlm 373-385.

Walker, Roger. Dyslipidemia. Dalam: Walker, Roger., dam Edwards, Clive (Ed.). Clinical Pharmacy and Therapeutics ( ${ }^{\text {rd }}$ edition). Spanyol: Churchill Livingstone,364. 2003. 